\title{
Editorial Essay: Iraqi Refugees, Beyond the Urban Refugee Paradigm
}

\author{
Géraldine Chatelard and Tim Morris
}

\begin{abstract}
Displacement and exile have been recurrent and durable phenomena affecting Iraqi society for the last 90 years. The process of forming an Iraqi state from the ruins of the Ottoman empire, which Aristide Zolberg has analyzed as a prime factor generating refugee flows, ${ }^{1}$ has been ongoing since 1920. Unfinished endeavours to build a state and nation have been characterized by almost incessant antagonistic claims over the nature of the state and national identity, the exercise of and access to political power, control of natural resources and border sovereignty. Political repression, violent regime change, redefinition of national identity, demographic engineering, and domestic or international armed conflicts have resulted in eviction, deportation, denaturalization, political emigration, and flight from violence. A large part of displacement in Iraq has been internal. But vast numbers of refugees and exiles have also formed a regional and global diaspora extending from Iran, Jordan, Israel, Syria, all the way to such distant emigration countries as New Zealand.
\end{abstract}

\section{Résumé}

La société irakienne est affectée depuis 90 ans de façon continue et prégnante par des déplacements de population et l'exil. Depuis le démembrement de l'empire ottoman en 1920, un état irakien a continuellement tenté de se constituer, ce qui a été analysé et identifié par Aristide Zolberg comme étant la source principale des mouvements de réfugiés. Les efforts pour construire un état et une nation en Irak ont constamment été minés par des revendications contradictoires et des luttes portant sur les questions de la nature de l'état, de l'identité nationale, de l'exercice et de l'accessibilité du pouvoir politique, du contrôle des ressources naturelles et de la souveraineté des frontières. La répression politique, les changements violents de régimes, les redéfinitions de l'identité nationale, les politiques démographiques, et les conflits armés régionaux et internationaux ont entraîné des évictions, des déportations, la dénaturalisation, l'émigration politique et la fuite devant la violence. Une grande proportion des déplacements de populations irakiennes est intérieure au pays. Toutefois, un nombre important de réfugiés et d'exilés forme une diaspora régionale et internationale qui s'étend à l'Iran, la Jordanie, Israël, la Syrie, et jusqu'à des pays d'immigration aussi éloigné que la Nouvelle-Zélande.

\section{Belated Recognition of Iraqi Displacement}

Despite their massive scale, displacement and other forms of involuntary migration from Iraq have so far largely escaped academic interest as topics in their own right. This is in sharp contrast with the large body of research devoted to Palestinian refugees. References to displacement within and from Iraq do exist, but they are scarce and scattered: they generally document displacement in relation to particular ethnicities or sects, episodes of conflicts, or political struggles. $^{2}$ So far, there has been little attempt to conceptualize Iraqi displacement as a political and social phenomenon or reflect on its historical depth and global scope. ${ }^{3}$

The displacement that resulted, directly or indirectly, from the toppling of Saddam Hussein's regime by a US-led coalition in April 2003 has appeared to most scholars as a crisis of unprecedented scale. Although many Iraqis started leaving the country as early as 2003 , it was only in 2007 , at the height of sectarian tensions and generalized insecurity, that advocacy and humanitarian organizations started releasing reports on Iraqi refugees in neighbouring countries. They particularly focused on Syria and Jordan, where the majority had fled, generating media coverage, especially in the US 
and UK, and a new interest from the part of mostly young scholars. The corpus of academic publications focusing on the post-2003 displacement trend has since been growing. ${ }^{4}$

It will come as no surprise that the 2007 surge of interest in Iraqi refugees closely corresponded with the beginning of humanitarian and policy engagement from the office of the UN High Commissioner for Refugees (UNHCR) and large donors, particularly the US and the European Union. Since then, research on Iraqis refugees has been largely policy driven, by or from the perspective of humanitarian aid agencies or refugee advocacy organizations. There are many justifications in favour of the policy bias in refugee research. ${ }^{5}$ There are also several shortcomings. In 2008, at a time when scholars were still mostly focusing on refugees in formal camps, and often limited their interest to refugee policy issues, Oliver Bakewell made a plea for researching forced migrants without using preconceptions. ${ }^{6} \mathrm{He}$ convincingly argued for considering the large number of self-settled refugees and aspects of their lives other than their interaction with aid programs, which tended to remain invisible to scholars. ${ }^{7}$

The new academic interest in self-settled refugees had in fact emerged in the early 2000s, inspired by the policy concerns of UNHCR which, in 1997, had issued its first policy on refugees in urban areas. However, scholarly publications on the belated recognition of the presence of refugees in cities only started to be available during the mid-2000s. This new area of refugee research has flourished in recent years due to the realization by a number of ground-breaking scholars that, in developing countries, the number of refugees found in non-camp settings, and particularly in urban areas, has increased considerably and that the paradigms used to understand the predicament of encamped refugees are not applicable to urban contexts. Beyond creating knowledge that reflects more closely the variegated experience of refugees, this approach also responds to the ethical imperative of better informing humanitarian policy to make it more relevant and likely to promote durable solutions for refugees.

\section{Urban Refugee Studies Rises Up Agenda}

Most humans now live in towns and cities. As the world urbanizes, so too do patterns of displacement. Increasingly, refugees, asylum seekers, returnees and internally displaced persons (IDPs) are not living in camps and rural areas but in towns and cities. They usually reside in impoverished neighbourhoods where governments are already struggling to provide their own citizens with basic services.

In recent years the growing attention to the phenomenon of displacement to urban areas is reflected in a spate of special issues of displacement-focused publications. ${ }^{8}$ In part, this interest has been fuelled by the decision of the High
Commissioner to focus on the subject for the annual dialogue convened by UNHCR in 2009. Urban refugee studies has gained traction and legitimacy as a subfield of refugee and forced-migration research, structured around a number of established scholars, and a growing bulk of literature. The field has developed analytical paradigms to reach a sociological understanding of specific refugee situations.

In urban areas most governments of host countries leave the management of refugees to UNHCR. The refugee agency often finds itself unable to provide the degree of protection and assistance it commonly provides in camps. Refugees may be hard to access. As their presence is often unauthorized, many keep a low profile and remain unregistered. Many host governments continue to regard camps as the only legitimate space for refugees, and UNHCR has tended, at least de facto, to adhere to this view. Often it has had little choice except to do so in the face of determined governments.

Many refugees, like IDPs, find urban settings attractive, offering better livelihood, social and self-sufficiency opportunities than rural or camp settings. Outside of the physical and legal space of camps, refugees in cities are often not granted a legal status under international or domestic law, thus remaining unprotected. For many the main consequence of lack of protection is having to pay bribes to government officials to move about cities, to trade, or to seek work. In urban areas, governments and political parties may frame refugees (as well as migrants and IDPs) as security threats to the existing social and economic fabric and strive to maintain their segregation to prevent their long-term settlement and integration. By implying that urban refugees should be contained, and that their stay is temporary, governments deny the possibility of accession to citizenship. Deemed a burden on national resources and often demonized, urban and other out-of-camp refugees may be faced with arbitrary state action and a hostile environment that creates xenophobia and fear among the refugees. This forces the refugees to seek anonymity, generally in urban slums, and adopt strategies of identity or physical concealment. As a result, refugees are prevented from access to existing services and decent livelihoods. Jacobsen ${ }^{9}$ and others have stressed that urban refugees could be an asset to regional economies if legal avenues were opened to allow them to pursue productive lives within formal frameworks. Fábos and Kibreab ${ }^{10}$ point to the development of transnational spaces within which refugees may rely on, or contribute to, remittances and other forms of support from social networks, often family based. They further note that refugees are often part of mixed-migration movements.

The urban turn in refugee studies, but also in advocacy, has had a strong impact on policy. In recent years, international 
emergency NGOs, together with UNHCR, have strived to adapt protection and assistance, the two pillars of their actions, to the challenges of operating in an urban environment. They have found it difficult to assess the needs of refugees intermixed among the population of the host country, to distinguish refugees, IDPs and migrants, and to deliver aid to those who either do not necessarily want to be identified or are extremely hard to identify as they live on urban peripheries far from UNHCR offices.

\section{Iraq Displacement Hastens Policy Change}

UNHCR recognized that the Iraqi refugee crisis was the biggest urban refugee crisis it had ever been obliged to address. The agency's reports of its operations in the main host countries of the Middle East, namely Syria, Jordan, and Lebanon, have also made it abundantly apparent that the crisis is different from previous urban refugee situations. The profile of the refugees, in their majority from the urban middle class, and the operational environment resulting from the development levels of Iraq and regional host states, together with the latter's reception policies for Iraqis, have presented humanitarian actors with some unprecedented challenges to existing protection and assistance models. Furthermore, the high political profile of the crisis, particularly in the US, has generated a donor response significantly greater than for other UNHCR caseload of urban refugees and IDPs. All these factors have allowed the agency to test new and costly approaches for delivering assistance, such as systematic outreach efforts, the provision of services to refugees and nationals alike on the basis of vulnerabilities, partnership with local NGOs, ${ }^{11}$ informing refugees via SMS or delivering cash through ATMs and employing refugees as outreach workers and counsellors. ${ }^{12}$ It is unlikely that these new models will be easily replicable in other urban refugee situations where funding levels for assistance are lower, the operational context in host countries is less favourable, and refugees have a more typical third-world profile.

Operations in favour of Iraqi refugees have also prompted UNHCR to revise its much-criticized urban policy, launching a new Policy on Refugee Protection and Solutions in Urban Areas in September 2009. Its roll-out correlated with the expansion of the refugee agency's activities in favour of Iraqi refugees. However the Iraqi refugee crisis raises questions about the universality of the new urban refugee policy. The document acknowledges the need to adapt to the specific context and the circumstances, capacities, and vulnerabilities of different groups and individuals within the refugee population. It provides a checklist to assess protection risks and vulnerabilities, describing in detail what these risks can be in extreme circumstances. On the other hand, very little guidance is given on how to identify and assess risks and vulnerabilities in situations where refugees are moving between middle-income countries, and where the protection environment is more favourable yet far from guaranteeing local durable solutions for refugees.

\section{Cumulative Causes of Displacement}

A consideration of the causes of displacement, which are extremely varied, helps understand the untypical profile of Iraqi refugees. As early as 2003, several thousands of political émigrés who were close associates of the Saddam Hussein regime left with their families and assets to find refuge in Arab countries, particularly Syria and Yemen, which welcomed them and offered them a stable status. That same year, the dismantlement of the Iraqi army and the order, passed by the US-led Coalition Provisional Authority, to remove all public sector employees who had been members in the Baath party left over half a million Iraqis without an income and disenfranchised. Among them were large numbers of professionals, such as medical doctors, engineers, teachers, and university professors. Furthermore, the lifting of the international embargo, imposed on Iraq by the UN-Security Council in 1990, gave way to a neo-liberal order which made the professional conversion of former civil servants difficult. ${ }^{13}$ This situation was compounded by an assassination campaign targeting secular intellectuals and professionals. Factors have therefore combined to force or convince tens of thousands of middle-class Iraqis to seek security and employment abroad, particularly in other Arab countries, from Jordan and Egypt all the way to the Gulf.

The major impetus for displacement was however the sectarian killings and cleansing affecting several areas of Iraq, particularly Baghdad, in 2006-8. During those years, Syria, the only country of the region with borders still universally open to Iraqis, received the largest number of refugees. Within this group, socio-economic and geographical backgrounds have been more varied than among political émigrés and professionals; however the majority still originates from the Baghdad middle class. Less economically or socially privileged Iraqis forced into displacement have remained inside the country as IDPs.

Further factors convincing many Iraqis to take the decision to leave are the constant deterioration of public services (at the time of writing, Baghdad only receives four hours of electricity a day) and the growing rate of unemployment (close to 30 percent). For many, it is a combination of various types of insecurity-physical, social, and economictogether with a sense of alienation from the new political and religious order now prevalent in Iraq that has prompted their departure and still prevents them from considering return a viable option. 
The pattern of displacement has not been a sudden and vast movement of people across borders, limited in time. Rather, it has been a constant out-migration since 2003, with a peak in 2006-7. Entire family groups have left with children and, at times, aging parents. Most did not flee abroad reactively, but after pondering their decision and making preparations, including selling properties. In several cases, the decision to leave Iraq came after an initial episode of internal displacement.

\section{Mixed Migration and Patterns of Mobility}

Iraqi refugees have to be understood as part of a large flow of mixed migration created by the major geopolitical and economic reconfiguration of Iraq which the US intervention has prompted. The integration of Iraq within the global free market, the war and reconstruction economy, and the possibility of travelling outside the country, strictly controlled under the Baath, afforded new opportunities for Iraqis with capital to invest in real estate and the private sector of neighbouring states, and in cross-border trade. This capital flow has benefitted the economies of countries hosting refugees from Iraq. Already in 2004-5, Iraqi businesses and community organizations started becoming highly visible in Damascus and Amman, the two major urban centres where refugees from Iraq have moved. Many of those Iraqis who left with financial and/or professional assets were able to successfully invest in other Arab countries, in some cases creating employment opportunities for less affluent refugees, generally in the informal sector. This has particularly been the case in areas of Damascus where Iraqis have gathered.

Not all Iraqi capital holders with a foothold in another Arab country are refugees. Many business entrepreneurs operate between Iraq, a base in the region, and the international market, and keep their families in security in Beirut, Amman, Cairo, the Gulf, or even a Western country. Dual residence is also a common feature of the Iraqi political class with duties carried out in Iraq, and family life lived elsewhere, including in the more affluent Arab capitals that also host refugees. Furthermore, Damascus, Amman, and Beirut play hub to activities for large numbers of temporary visitors from Iraq: patients seeking high quality medical care, university students pursuing an education, pilgrims to Shiite shrines in the Syrian capital, holiday visitors escaping the summer heat at home, and so on. ${ }^{14}$

\section{Migration Regimes Sharpen Socio-economic Differences}

Overwhelmingly from the middle and upper classes, and with urban backgrounds, Iraqi refugees originate from a middle-income, oil-producing country with what were, at one time, good social and education services, which progressively deteriorated over several decades due to the Iran-Iraq war of the 1980s, the international sanctions applied between 1990 and 2003, and the US-led invasion. The refugees have first-world expectations in terms of living standards, medical care, and quality of education for their children. Exile has sharpened social stratification between those who have maintained socio-economic status and those who have not, creating anxieties and uncertainty among the latter.

The Arab states receiving Iraqi refugees are themselves middle-income countries generally experiencing a crisis of the welfare state and increasingly adopting neo-liberal policies. They have a vested interest in offering privileged access and status to Iraqis with capital to invest or to spend on the local market and services, regardless of the reasons why they have come to stay. Each of these countries, particularly those sharing a border with Iraq, also envision their policy vis-à-vis Iraqis willing to enter or stay on their territory within specific geopolitical and domestic agendas. None of the main host countries receives Iraqis within a refugee regime. Rather, Iraqis are fitted within migration regimes that tend to favour those with financial, professional, or political assets.

Syria has been the most inclusive host facilitating the near universal entry of Iraqis, and the delivery and renewal of one-year residence. The government has also offered Syrian passports to high-level Iraqi Baathists. By contrast, Lebanon only allows entry to Iraqis with financial means, and has requested that those who want to stay long-term find a local sponsor to be granted residence permits. Many Iraqis who entered illegally or remained without a sponsor have been detained. Jordan and Egypt restrict entry based on financial means or professional guarantees. They grant one-year residence to holders of financial capital or legal work contracts. The authorities however apply a tolerance regime to Iraqis inside the country who fail to meet residence requirements, and they refrain from systematic detention or deportation.

In all cases, because Iraqis are treated as migrants, their access to the work market is governed by labour laws applying to foreigners. The general trend has been to deny work permits to Iraqis except in professions where skills are in demand. Since labour markets in host countries are already congested, and unemployment high in sectors where educated Iraqis have competences, vast numbers of refugees have been left without employment or forced to seek informal jobs below their qualifications. This has greatly contributed to the sense of insecurity and anxiety of Iraqi individuals and families who have used their savings and survive on remittances from relatives in Iraq or the diaspora 
to strive to maintain living standards, particularly quality education for their children.

As migrants, Iraqis are free to settle where they wish, in urban or rural areas, and to rent or even buy properties when then can so afford. Residential patterns reflect socioeconomic status, real or aspired, as many Iraqis make desperate financial efforts not to move to less affluent areas in large Arab cities. Iraqi neighbourhoods have developed in the centre or the periphery of Damascus, Amman and Cairo with ethnic businesses catering for the needs of the new residents. ${ }^{15}$ In Amman, for example, Iraqis are known to be scattered across the city. The most affluent ones cluster in a number of residential neighbourhoods in the west part of the capital where a high-end Iraqi business area has also developed. Less well off Iraqis have regrouped alongside poorer Jordanians, Palestinian refugees, and labour migrants in the eastern part of Amman. This is also where local and international NGOs have concentrated their social services.

\section{Refugee Policy and Assistance}

UNHCR operates through agreements or memorandums of understanding with Arab host governments whereby responsibilities for refugee assistance and protection are shared. Michael Kagan provides an in-depth analysis of the modalities and implications of UNHCR's role as a "surrogate state' in the Middle East." 16 He also sees the Iraqi refugee crisis as exemplifying the "grant compromise" of global refugee policy, namely burden sharing: high donor interest has allowed UNHCR to mobilize considerable resources channelled to services for refugees delivered by the UN refugee agency, international NGOs, or host governments.

However, there are marked differences between host countries in their willingness to open state-run services to Iraqis. Syria and Jordan allow Iraqis to use government medical facilities and schools regardless of their residence status and situation vis-à-vis UNHCR. In Jordan and, to a lesser extent, Syria, the vast amount of international aid generated by the Iraqi refugee crisis has served to upgrade public facilities that benefit host-country nationals more than the refugees from Iraq. ${ }^{17}$ By contrast, Lebanon has opened public schools and medical facilities only to Iraqis registered with the UN refugee agency, whereas Egypt has closed access for all Iraqis to public services and has impeded alternative service provision by NGOs. UNHCR also directly operates programs such as the delivery of cash assistance to needy refugees, and has set up mechanisms to coordinate between different assistance providers.

Syria does not fit neatly into Kagan's analysis. The country's almost constant open-door policy to Iraqi refugees, and the universal access it grants them to public facilities while receiving much less donors' assistance than Jordan, require a consideration of the country's regional and international political agendas. In general, it can be argued that the relative favourable "protection space' afforded underprivileged Iraqi refugees by host countries is as much the result of economic and geopolitical calculations by host governments as the effect of international assistance and UNHCR's assumption of the role of a surrogate state.

\section{Resettlement and Asylum}

The high interest of resettlement states is the second pillar of the "grand compromise" between regional host states and Northern donors. All Arab host countries envision the stay of Iraqis, particularly those dependant on assistance, as temporary and rule out naturalization. ${ }^{18}$ Even Iraqis with assets and a residence permit share with their less advantaged conationals a feeling of uncertainty about the future because there is no guarantee that host states will not shift policy and force them to return to Iraq. The current instability in the region, particularly in Syria and Egypt, exacerbates this feeling and it appears that refugees have returned to Iraq in unprecedented numbers over the first quarter of $2012 .{ }^{19}$ In this context, probably the main reason why Iraqis register with UNHCR is to access third-country resettlement.

The resettlement program has taken up a large amount of UNHCR staff time and financial resources. In 2010, Iraqis were the largest group of beneficiaries of UNHCR-facilitated third-country resettlement programs $(26,700) .{ }^{20}$ The US has accepted far more Iraqis than the other developed country (including Canada, the Nordic countries, Australia and New Zealand) that each year participates in the program. ${ }^{21}$ As of April 2012, 58,810 Iraqi refugees had arrived in the US. Numbers have been declining since arrivals peaked in 2009. ${ }^{22}$ The process has been extremely slow with a large number of Iraqis waiting well over a year between admission and actual resettlement because of several levels of security screening. ${ }^{23}$ This delay maintains Iraqi individuals and families in an unbearable situation of uncertainty, keeping them dependent on humanitarian assistance or depletion of personal resources; thwarts their efforts to plan for their future and, often, that of their children; and forces an increasing number to return to Iraq where insecurity still prevails.

While the US has been the main resettlement country, Western European states have received the largest number of in-country asylum applications from Iraqis, with Sweden topping the list. Another unusual aspect of the ongoing crisis of Iraqi displacement is that there are considerable numbers of Iraqi asylum seekers whose claims have been refused but who are in a legal limbo as European states seek to enforce decisions to forcibly return them to Iraq-despite 
UNHCR advocacy. Judgments in 2010 by the European Court of Human Rights blocking forced returns were followed by a resolution of the Iraqi parliament in June 2012 banning the forced return of tens of thousands of failed asylum seekers and threatening to fine airlines that take part in deportation programs. There appears to be no precedent for the post-crisis legislature of a refugee-producing state to refuse to take back its own nationals.

\section{Assumptions about Refugees' Needs}

The unusual profile and first-world expectations of the refugees, the desire of governments to assert control and sovereignty over humanitarian intervention, and the role UNHCR has come to assume as a "surrogate state" for nonPalestinian refugees in the region have rendered models developed to respond to the needs of urban refugees in extremely different circumstances ill-fitted to the situation of the Iraqis.

Interventions initially proceeded from a series of assumptions about the needs and vulnerability of the refugees. In its early stages, programming was emergency-oriented and aimed at meeting such needs as access to primary health care and basic education. Refugees were thought to be at threat of arrest and detention, refoulement, harassment, exploitation, discrimination, and vulnerability to sexual and gender-based violence. Over the last two years, UNHCR and its implementing partners have made considerable progress in refining their approach, responding to Iraqi refugees' actual needs: secondary and tertiary healthcare psychosocial programs (particularly mental health for survivors of torture), remedial and higher education, skills maintenance and development.

\section{“Guesstimating” Numbers}

Arguably, the most difficult assumption to dislodge has been that there are vast numbers of unregistered Iraqi refugees, fearful and in hiding among the host population. Indeed, the original estimates of the number of Iraqi refugees put forward by host countries at the April 2007 donor conference organized in Geneva by UNHCR were above two million. In 2009, the number of registrations with UNHCR peaked at just above 310,000 throughout the Middle East, with 220,000 in Syria and 52,000 in Jordan. When the expected number of refugees failed to register, humanitarian actors, advocacy organizations, the international media, and refugee scholars all concurred that uncounted numbers of Iraqis were in hiding in the cities, fearing arrest and deportation.

UNHCR and NGOs inaugurated outreach programs that considerably stretched their human and financial resources to try to locate these "invisible" refugees and convince them to register. However, after a couple of years of these costly efforts, concerned agencies came to admit that, at least in Syria and Jordan, over 90 percent of those Iraqis in need of protection and/or assistance were already registered.

This is not to say that the figure of 310,000 represents 90 percent of Iraqis who left to escape political or criminal violence, or the new social, moral, and economic order brought about by the change of regime, which for many has proven disorientating. However, it is likely that other Iraqis who have relocated from Iraq without seeking registration with refugee or asylum agencies have to be approached in terms different from those offered by both the international refugee regime and refugee studies.

Difficulty in estimating numbers of refuges is compounded by the mixed nature of Iraqi migration to neighbouring countries and the circulation of refugees between a host country and Iraq. ${ }^{24}$ This situation is not unlike that of other refugee crises worldwide after the intensity of conflict decreases. Afghanistan provides another major example of the phenomenon.

\section{Policy Effects of Inflated Numbers}

There has been much discussion about the size of the Iraqi refugee population as well as a tendency among practitioners and scholars to base accounts, assessments, narratives, and analysis on the highest figures publicized by host governments. ${ }^{25}$ There has also been much debate behind closed humanitarian doors and academic institutions about the relevance of speculating on the number of refugees when what mattered was the amount of suffering the displacement experience was inflicting.

There are at least some reasons for arguing that inflating the number of refugees has had direct detrimental effects on their immediate well-being and future. Kate Washington and Harriet Dodd, ${ }^{26}$ reflecting on their experience working with a large international NGO in Jordan since 2007, concur that the adherence of large donors and UNHCR to very high figures - up to 750,000 Iraqis in Jordan at some pointnegatively impacted the capacity of operational aid agencies to plan, tailor, and implement programs in the best interest of the refugees. The disproportionately large amount of funding flowing from donors, particularly the US government, also had negative consequences: the rapid expansion of agencies applying ready-made models and the resistance to change in approach even as it became obvious that the Iraqi refugee situation was not, except maybe in its very early stage, a humanitarian crisis; competition between NGOs for, and retention of Iraqi beneficiaries; agencies focusing on meeting pre-developed targets rather than on quality and goal of the services; the difficulty of developing a sustainable strategy focused on a realistic number of beneficiaries; 
and the development of an assistance-seeking behaviour in the Iraqi community. With some nuances, these remarks are equally valid for Syria. ${ }^{27}$

The perception of the Iraqi refugees by host communities has also been affected by their representation in official discourse, in the media, and by many international NGOs as hordes of people preying on scarce national resources or as potential exporters of the kind of sectarian conflict which raged in Iraq in 2006-7. ${ }^{28}$ These representations have, in several cases, created xenophobia and tensions between nationals and refugees. They have also provided justification for authoritarian governments to enhance their security apparatus and restrict the entry of Iraqis fleeing violence. ${ }^{29}$ Unfortunately, at the time of writing, these patterns are being reproduced in relation to Syrians seeking refuge in neighbouring countries while fleeing massacres and repression at home. These misconceptions have also undermined advocacy efforts by UNHCR and international NGOs to encourage host governments to support refugees' selfsufficiency through allocation of work permits, vocational training, or credit schemes for small businesses. Which government, anywhere in the world, would willingly open its formal labour market to a foreign work force thought to represent up to 10 percent of the national workforce?

Another distorting effect of inflated numbers has been sidelining of UNHCR resettlement endeavours and the fact that the program has provided ammunition to critics of the US intervention in Iraq. In January 2011, UN High Commissioner for Refugees António Guterres stated that 60,000 Iraqi refugees had departed to resettlement countries while another 60,000 were still in need of resettlement. In statistical terms, there are at least two contrasting ways of measuring the overall resettlement efforts. One is to look at the ratio of resettled refugees to the numbers of Iraqi refugees-according to host governments about two million. This would represent 3 percent of the total estimated refugees already resettled, and another 3 percent in need of resettlement. The other way is to take as a basis the number of Iraqi refugees registered with UNHCR throughout the region. If and when the target of 120,000 is met, 40 percent of the total number of Iraqi refugees registered in 2009, or 46 percent of those registered in early 2011, will have been resettled. Considering the unreliability of the estimates used by host governments, the second set of figures is more likely to reflect the size of the efforts and the remaining needs. Here too, it may make a difference for policy makers and public opinion in resettlement countries to be informed by refugee advocates and the media that 60,000, and not two million, refugees are desperately waiting to be granted the safety and stability which they hope resettlement will provide them.

\section{Towards Improved Understanding of Iraqi Displacement}

Social scientists have tended to see those displaced from Iraq almost exclusively through paradigms developed to account for the experience of urban refugees facing extremely different circumstances. The caseload of Iraqi refugees has not been typical urban refugees of the kind now found throughout the world. Arguably, the category of urban refugees has been too rigid, unable to adequately describe either the situation of displaced Iraqis or to analyze the universal applicability of programs to assist them.

This has prompted several contributors in this issue, particularly those with a strong ethnographic insight, to engage with Iraqi refugees on a different plane. Distancing themselves from policy-informed analytical frameworks, they anchor their discussions within current social science debates, exploring the nexus between gender and citizenship among women refugees; the dialectic of provisional return and place-making; social stratification, class, and the effects of neo-liberalism on refugees; the production and reproduction of state sovereignty by international NGOs; the impact of exile on relations within the nuclear family and rebuilding of roles and meaning; or migrant's social capital and its role in information sharing about the resettlement process.

Essays in this issue also aim to contribute to some crucial policy issues: the effect on refugees of irregular migration and refugee containment measures adopted by the more wealthy states; the politics of resettlement, particularly in the US and EU; the process of accommodation taking place between refugees and host societies and governments in countries of the Middle East; the necessity for humanitarian actors to recognize regional and international mobility as legitimate coping mechanisms for refugees; and finally the urgency to look beyond conventional approaches to durable solutions to the plight of the refugees.

The three opening contributions examine the legacy of previous trends of refugee migration from Iraq, so far largely disregarded by scholars and the humanitarian community. Thousands of Iraqis aspiring to reach safety from the regime of Saddam Hussein in Australia, which they expected to be a liberal asylum country, have spent years stranded in transit countries in Southeast Asia with no durable solution in sight: they are now joined by new arrivals from Iraq. In Middle Eastern host countries, where no stable legal status is available to poor refugees, UNHCR has fitted the pre2003 Iraqi caseload into resettlement programs that would force some of these long-term refugees to sever the family ties they have built in the host country. More fortunate escapees from the Baathist regime, who managed to rebuild a secure life in exile, have taken advantage of post-2003 
opportunities to go back to Iraq, only to then realize how much home, and their sense of it, had changed, making permanent return impossible.

\section{Iraqis Stranded in Indonesia}

Sue Hoffman addresses the experience of Iraqi asylum seekers stranded in Indonesia after failing to reach Australia through irregular migration in the late 1990s. Often experiencing multiple traumas-from persecution at home to unsuccessful boat journeys trying to reach the coast of Australia, in several cases resulting in the death of loved ones-these refugees are difficult to resettle, because they represent the old caseload of pre-2003 refugees from Iraq. They have fallen through the gaps of the international refugee protection system and their experience of "wasted lives" is poignant. This significant group is at the core of recent policy debates in Australia, not least because of the continuous furor over boat arrivals and the centrality of antirefugee rhetoric in political discourse (blaming Iraqis, and other asylum seekers, as "queue-jumpers"). The contribution documents the action of UNHCR and the International Organization for Migration (IOM) in Indonesia and highlights the essential problem with Australian demonization-that there is, effectively, no regional queue for them to "jump." The paper also accounts for arrival, along the same routes, of new Iraqis fleeing the Middle East after 2003, and the reasons behind the refugees' choice of this migratory route.

\section{Iraqi Women Returning from Australia}

Katie Vasey examines the experience of Iraqi women who relocated to Australia as part of Australia's Refugee and Humanitarian Program during the years of international sanctions against Iraq, and who returned to visit their homeland after the fall of Saddam Hussein. The author explores these women's experiences of provisional return to Iraq, and questions how their return influences their "home" making in Australia. Through narratives of longing, belonging, return to Iraq and return to Australia, Vasey interrogates the complex, contradictory, and ambivalent relationships that Iraqi women developed with both their host and home countries and how this impacted upon their well-being. Iraqi women expected to experience a feeling of well-being upon return to Iraq, as they stepped back into the "home country," an idealized place that had allowed them to cope with the anxieties of exile. Such feelings of well-being, security, and being "at home" crumbled with the realization that the social environment had irreversibly changed, and that returning permanently to Iraq was impossible. This realization was not only based on the fact that the country had, in their absence, been subjected to ongoing destruction and devastation, but also related to the transformations they had undergone in Australia.

\section{Divorced Iraqi Women in Jordan}

Susan MacDougall explores the nexus between divorce, immigration laws, and refugee status for Iraqi women in Jordan who had arrived in the country before 2003 and were previously married to Jordanian men. The legal systems effectively fence off divorced women in Jordan, with child custody laws preventing them from leaving and citizenship laws denying them the possibility of naturalization, reinforcing their vulnerability and social exclusion. These women register with UNHCR as an alternative to their lack of status, but are funnelled into a refugee management regime that envisions Jordan merely as a place of transit for refugees. This is inappropriate for women who have lived in the country for over a decade and have children with Jordanian citizenship. Central to the discussion are issues of gender and citizenship, or rather how citizenship is gendered in particular ways in countries of the Middle East, and how the refugee regime is ill-suited to provide durable solutions to women whose situation does not fit neatly into existing legal categories.

\section{Class and Rejection of the "Refugee" Label}

By introducing the class variable, Elisa Pascucci offers a complex view of what displacement means to those who do not want to be called "refugee." The author challenges typical portrayals of Iraqis in the Middle East while prompting the reader to consider the ways in which vulnerability and class status may coexist. Her informants underplay ethnic and religious differences, and emphasize rather social stratification, past or created by displacement, as the most divisive factor among Iraqis. Class divides in exile between those who can maintain stability and security through financial capital, taking advantage of neo-liberal investment policies and unconcerned by the regime of international refugee assistance, and those who cannot, or who cannot any more after a slow process of downward social mobility during which they strived to maintain social status through remittances and/or savings. What Pascucci deems "middleclass anxieties" about children's education and standards of living pose challenges to international assistance providers used to dealing with other types of refugee vulnerabilities. Pascucci reminds us that, beyond the focus of humanitarian agencies and legal scholars on the legal and policy context of reception in host countries, social and economic factors are strong determinants of the refugee experience. She also argues that neo-liberal policies and the political economy of bilateral relations (such as trade and investment linking countries of origin and settlement of the displaced) need 
to be factored into any meaningful analysis of the refugee experience and context of vulnerability.

\section{INGOs and State Sovereignty}

Sophia Hoffmann takes the reader to a different plane-that of humanitarianism-unveiling the underlying tendency among mainstream INGOs to work within social relations established by and, in essence, reproducing the hegemonic power of state sovereignty. INGO practices towards Iraqi refugees in Damascus reveal how the "sovereign ideal" of territory, nation, and government informs techniques of migration management, which in turn reproduces this ideal. The author makes a point crucial to an understanding of how the humanitarian regime-whose perspective has dominated the literature on Iraqi refugees-has also blurred an appreciation of the variety of Iraqi experiences in exile and in migration. She notes that professional INGOs were prevented by the Syrian government from amassing knowledge about the Iraqi population and could not conduct the needs assessments that usually form the basis of aid-projects. INGOs in Damascus thus based their interventions largely on assumptions about the Iraqi population, which flowed from established ideas and tropes about refugees, intimately connected to sovereignty and sovereign exclusions. INGO rhetoric, and the academic production that adheres to this rhetoric, reduce the extremely varied existence of Iraqis in exile, which also includes successes, opportunities, strength, health, and self help, to that of suffering and weakness, and in this contribute to the construction of sovereignty. Yet, as the author notes, refugees negotiate, experience, and subvert in multiple ways the sovereignties projected by the state and the INGOs.

\section{Rebuilding Roles and Meaning within the Family} The contribution by Muriel Génot-together with Muath Asfoor, and Hala Hammad who assisted her in her therapeutic engagement with Iraqi refugee children and their fathers as part of the activities of the NGO Center for Victims of Torture (CVT)-brings to the fore the crucial question of how exile affects relations within the nuclear family. The authors account for an innovative experience of psychological counselling with Iraqi refugees in Jordan responding to a request from fathers who had seen their protecting role shattered by violence and displacement. CVT offered to organize regular meetings of small groups where fathers and children worked together with counsellors on rebuilding roles and re-establishing communication though endowing violence and exile with meanings children could access and fathers could utter. One of the key contributions of the paper is that humanitarian intervention does not necessarily reproduce existing models as long as practitioners are ready to listen, propose, engage on par with refugees, and take the risk of innovating. Beyond its disciplinary underpinnings, and its value for practitioners, the paper makes a particularly strong contribution to the literature on refugees' agency. It demonstrates in a powerful yet moving way how, during periods of uncertainty and temporariness, such as between flight and resettlement, refugees can productively engage at the family level to act upon their own future.

\section{Information Sharing among Refugees}

Adam Saltsman's focus remains with Iraqi refugees in Jordan. He provides insight into the effects of information sharing (or lack thereof) between international organizations (especially UNHCR) and displaced populations. The author argues that information campaigns by international refugee agencies often falter for two crucial reasons beyond resource scarcity. First, agencies disseminating information are often under pressure to curb the outflow of migrants from the Global South, and as a result, information provision has tended to be coloured by efforts to control or protect against forced migrants' movement or desires. Second, these agencies do not typically consider or engage with migratory capital, including migrants' informal networks for sharing knowledge about the migratory process, often based on transnational relations. As a case study, the author explores the lived experiences of refugees vis-à-vis both the official information from humanitarian agencies and their informal networks that are transnational in nature. Saltsman makes a compelling case in favour of initiatives contributing to migratory capital, a set of resources on which forced migrants often depend just as much as on the protection of international agencies. He argues that, rather than relying on a model of universal protocol, UNHCR and other agencies should both increase their transparency visà-vis the refugee and engage the sorts of local and transnational initiatives that spring up as survival mechanisms in contexts of displacement.

\section{Local Accommodation}

Dawn Chatty and Nisrine Mansour offer a more policyoriented contribution to this issue based on a study of perception among refugees and policy makers in the three main host countries of the Middle East, who are found to be more pragmatic than the international aid community and to broaden the scope for durable solutions. The authors identify an ongoing process of local accommodation that takes please in Syria, Lebanon, and Jordan in lieu of official integration, a term widely rejected because of the sensitivity to the protracted Palestinian refugee situation. Accommodation is the outcome of new patterns of inter- and 
intra-social relations between host and refugee communities and within Iraqi communities, and is not problem-free as mutual recriminations and competing claims between local and refugee communities are reported. Another important element the authors highlight is the fluid movement of Iraqis back and forth to Iraq as an important mechanism for improving life opportunities and reducing family risk. Mobility is also a common feature of Iraqi exiles' transnational networks, built over decades of displacement from Iraq and linking family members scattered on several continents. The authors make a case for recognizing regional and transnational mobility as a risk-management strategy for refugees for whom the three classic durable solutions are largely inapplicable. They also regret that this mobility is often looked at sceptically by many in the humanitarian aid regime as it raises questions regarding how well Iraqis fit into the "category" of refugee.

\section{Return and Remigration}

Echoing and complementing Chatty and Mansour's paper, Vanessa Iaria's essay provides an overview of the complex political and economic context within which Iraqis who fled to Syria or Jordan after 2003 make decisions regarding return and remigration. She found that Iraqi refugees' decision to return is driven less by improvements in Iraq than by their desire to rebuild their lives back home and overcome the difficult legal and socio-economic conditions in neighbouring countries. However, the micro and macro transformations occurring in post-Saddam Iraq also have a strong bearing on refugees' return and reintegration in their home communities. In the absence of security at home and durable perspectives in a neighbouring country, several of the Iraqis Iaria interviewed engage in transnational mobility and livelihoods as a survival mechanism. The article makes two notable contributions to refugee policy. One is that the voluntary repatriation of refugees cannot be interpreted solely as an evidence of progress in a series of post-conflict issues, including restoration of security and political stability. The other is that the international refugee regime's concern with governing refugees' movements after repatriation by stopping remigration may hamper the natural transnational practices that refugees have developed as alternative livelihood strategies in the absence of other, durable solutions.

\section{Limits of Third-Country Resettlement}

Chantal Berman's closing contribution stands as a counterpoint, illustrating the inadequacy of third-country resettlement as the main durable solution envisioned so far by the humanitarian regime for Iraqi refugees. The rationale for resettlement policies is to be found elsewhere than in the humanitarian needs of the refugees. Using a detailed comparative policy focus, the author examines US and EU policies regulating the selection and admission of Iraqi refugees since 2003, focusing on the divergent political priorities and structural considerations underpinning variations in resettlement levels during this time. The author argues that US resettlement of Iraqi refugees is primarily an element of foreign policy, defined by strategic objectives in Iraq and the surrounding region, whereas admissions to the EU reflect ongoing intra-European debates surrounding the construction and modification of the Common European Asylum System (CEAS). While Europeans opposed to Iraqi resettlement have argued for sole US responsibility for Iraqis' humanitarian needs, Bush Administration officials justified policies of minimal resettlement through a causational de-linking of the US invasion and the ensuing refugee crisis. Refugee resettlement (or a calculated lack thereof) remains one tool among many in the diplomatic and strategic arsenal of the United States on a global scale. Finally, comparing US and EU policies vis-à-vis Iraqi refugees raises questions about states' accountability for refugee-producing policies, and about the corresponding levels of aid and resettlement required to offset this "responsibility."

\section{Notes}

1. Aristide Zolberg, "The Formation of New States as a Refugee-Generating Process," Annals of the American Academy of Social and Political Science 467 (1983).

2. Major references providing direct or indirect account of this long history of displacement are: Abbas Shiblak, The Lure of Zion: The Case of the Iraqi Jews (London: Saqi Books, 1986); Yitzhak Nakash, The Shi'ites of Iraq (Princeton: Princeton University Press, 1994); Pierre-Jean Luizard, "Iraniens d'Irak, une élite religieuse chiite face à un état Sunnite," Cahiers du Cemoti 22 (1996); Nelida Fuccaro, "Ethnicity, State Formation, and Conscription in Postcolonial Iraq: The Case of the Yazidi Kurds of Jabal Sinjar," International Journal of Middle East Studies 29, no. 4 (1997); Maarten Michiel Leezenberg, "Between Assimilation and Deportation: History of the Shabak and the Kakais in Northern Iraq," in Syncretistic Religious Communities in the Near East, ed. Krisztina Kehl-Bodrogi, Barbara Kellner-Heinkele, and Anke Otter-Beaujean (Leiden: Brill, 1997); Madawi Al-Rasheed, Iraqi Assyrian Christians in London: The Construction of Ethnicity (Lewiston, NY: The Edwin Mellen Press, 1998); Ismet Cheriff Vanly, “The Forgotten Feili Kurds of Iraq," in Kurdish Exodus: From Internal Displacement to Diaspora, ed. Mohammed Ahmed and Michael Gunter (Sharon, MA: Ahmed Foundation for Kurdish Studies, 2002); Ali Babakhan, L'Irak, 1970-94, déportation des chiites (Paris: A. Babakhan, 1994), and Les Kurdes d'Irak. Leur histoire et leur déportation par le 
régime de Saddam Hussein (Paris: A. Babakhan, 1994); David Romano, "Whose House Is This Anyway? IDP and Refugee Return in Post-Saddam Iraq," Journal of Refugee Studies 18, no. 4 (2005); Hala Fattah, "Les autres Irakiens: émigrés et exilés d'avant 2003 en Jordanie et leurs récits d'appartenance," Revue des mondes musulmans et de la Méditerranée (2007); Mara Shoeb, Harvey Weinstein, and Jodi Halpern , "Living in Religious Time and Space: Iraqi Refugees in Dearborn, Michigan," Journal of Refugee Studies 20, no. 3 (2007); Vanessa Johnston, Katie Vasey, and Milica Markovic, "Social Policies and Refugee Resettlement: Iraqis in Australia," Journal of Critical Social Policy 29, no. 2 (2009); Didem Danis, Migration de transit et réseaux sociaux: le cas des migrants irakiens en Turquie (Saarbrücken: Éditions universitaires européennes, 2010); Orit Bashkin, New Babylonians: A History of Jews in Modern Iraq (Stanford: Stanford University Press, 2012).

3. This has been attempted by Géraldine Chatelard, "Migration from Iraq between the Gulf and the Iraq Wars (19902003): Historical and Socio-spatial Dimensions," Working Paper 09-68, COMPAS-Centre on Migration, Policy and Society (Oxford: Oxford University, 2009); Nabil Al Tikriti, "There Go the Neighbourhoods: Policy Effects vis-à-vis Iraqi Forced Migration," in Dispossession and Displacement: Forced Migration in the Middle East and Africa, ed. Dawn Chatty and Bill Finlayson (New York and Oxford: Oxford University Press, 2010); Géraldine Chatelard, "What Visibility Conceals: Re-embedding Refugee Migration from Iraq," in Dispossession and Displacement: Forced Migration in the Middle East and Africa, ed. Dawn Chatty and Bill Finlayson (New York and Oxford: Oxford University Press, 2010); Géraldine Chatelard, "The Politics of Population Movements in Contemporary Iraq: A Research Agenda," in Writing the History of Iraq: Historiographical and Political Challenges, ed. Riccardo Bocco, Jordi Tejet, and Peter Sluglett (London: World Scientific Publishers/Imperial College Press, forthcoming).

4. A non-exhaustive list includes: Ashraf al-Khalidi, Sophia Hoffman, and Victor Tanner, "Iraqi Refugees in the Syrian Arab Republic: A Field-Based Snapshot" (Washington, DC: The Brookings Institution, 2007); Philip Marfleet, "Iraq's Refugees: 'Exit' From the State," International Journal of Contemporary Iraqi Studies 1, no. 3 (2007); "Special Issue-Iraq's Displacement Crisis: The Search for Solutions," Forced Migration Review (June 2007); Markus Sperl, "Fortress Europe and the Iraqi 'Intruders': Iraqi Asylumseekers and the EU, 2003-2007," New Issues in Refugee Research, Research Paper no. 144 (2007); Philippe Fargues, Saeed Al-Masry, Sara Sadek, and Azza Shaban, "Iraqis in Egypt: A Statistical Survey in 2008" (Cairo: The American University in Cairo, Center for Migration and Refugee Studies, 2008); International Crisis Group, "Failed responsibility: Iraqi refugees in Syria, Jordan and Lebanon," (Brussels: International Crisis Group, 2008); Reinoud Leenders, "Iraqi Refugees in Syria: Causing a Spillover of the Iraqi
Conflict?," Third World Quarterly 29, no. 8 (2008); "Special Edition-Iraq's Refugee and IDP Crisis: Human Toll and Implications," Viewpoints (Washington, DC: The Middle East Institute, 2008); Géraldine Chatelard, Oroub El-Abed, and Kate Washington, "Protection, mobility and livelihood challenges of displaced Iraqis in urban settings in Jordan" (Geneva: International Catholic Migration Commission, 2009); Géraldine Chatelard and Humam Misconi, "Regional Perspectives on Iraqi Displacement: A Research Report and Discussion Paper," in Resolving Iraqi Displacement: Humanitarian and Development Perspectives (Washington, DC: The Brookings Institution, 2009); Philip Marfleet and Dawn Chatty, "Iraq's refugees-beyond 'tolerance," RSC Forced Migration Policy Brief no. 4 (Oxford: Refugee Studies Centre at the University of Oxford, 2009); Emily Minnick and Noheier Nashaat, "'Stuck' in Egypt: Iraqi refugees' perceptions of their prospects for resettlement to third countries and return to Iraq" (Cairo: American University in Cairo, Centre for Migration and Refugee Studies, 2009); Joseph Sassoon, The Iraqi Refugees: The New Crisis in the Middle East (New York, NY: I.B. Tauris, 2009); Patricia Weiss Fagen, "Iraqi Refugees: Seeking Stability in Syria and Jordan" (Georgetown University, Center for International and Regional Studies, 2009); Géraldine Chatelard, "Cross-Border Mobility of Iraqi Refugees," Forced Migration Review no. 34 (2010); Angela Nickerson, Richard A. Bryant, Zachary Steel, Derrick Silove, and Robert Brooks, "The Impact of Fear for Family on Mental Health in a Resettled Iraqi Refugee Community," Journal of Psychiatric Research 4, no. 4 (2010); Géraldine Chatelard, "Iraqi Refugees: Making the Urban Approach Context-Specific," Humanitarian Exchange no. 51 (2011); Géraldine Chatelard, ed., Iraq Study Group, in Refugeecooperation.org Project (Washington, DC: Middle East Institute, and Paris: Fondation pour la recherche stratégique, 2011); Kathryn Libal and Scott Harding, "Humanitarian Alliances: Local and International NGO Partnerships and the Iraqi Refugee Crisis," Journal of Immigrant and Refugee Studies 9, no. 2 (2011); Philip Marfleet, ed., "Special Issue-Iraq's Displacement," International Journal of Contemporary Iraqi Studies 5, no.2 (2011); Victoria Mason, "The Im/mobilities of Iraqi Refugees in Jordan: Pan-Arabism, 'Hospitality' and the Figure of the 'Refugee," Mobilities 6, no. 3 (2011); Tahir Zaman, "Jockeying for Position in the Humanitarian Field: Iraqi Refugees and Faith-Based Organisations in Damascus," Disasters 36, no. 1 (2012).

5. See, particularly, Karen Jacobsen and Lauren B. Landau, "The Dual Imperative in Refugee Research: Some Methodological and Ethical Considerations in Social Science Research on Forced Migration," Disasters 27, no. 3 (2003).

6. Oliver Bakewell, "Research Beyond the Categories: The Importance of Policy Irrelevant Research into Forced Migration," Journal of Refugee Studies 21, no. 4 (2008).

7. Idem, 433. 
8. For example: Forced Migration Review, no. 34, 2010; the Journal of Refugee Studies 19, no. 3 (2006); Refuge 24, no. 1 (2007), and Disasters, July 2012 Special Issue: Urban Vulnerability and Humanitarian Response. See also, Tim Morris, "Selected Bibliography: Displacement to Urban Areas," UNHCR, August 2011, accessed 10/07/2012, http://www .unhcr.org/4b0ba1209.pdf.

9. Karen Jacobsen, "Editorial Introduction: Refugees and Asylum Seekers in Urban Areas: A Livelihoods Perspective," Journal of Refugee Studies 19, no. 3 (2006).

10. Anita Fábos and Gaim Kibreab, "Urban Refugees: Introduction," Refuge 24, no. 1 (2007).

11. Libal and Harding, "Humanitarian Alliances"; Chris Skopec, Natalia Valeeva, and Mary Jo Baca, "Anticipating the Unexpected: Urban Refugee Programming in Jordan,” Refugeecooperation.org Project (2010), accessed 17/06/2012, http://www.refugeecooperation.org/publications/Iraq /02_skopec.php.

12. Sayre Nyce, “ATM Cash Assistance: Does It Work?,"Forced Migration Review 34 (2010).

13. Marfleet, "Iraq's Refugees."

14. As shown by the yet unpublished works of Ane Mannsåker Roald, a PhD candidate at the University of Oslo investigating the role of the Iraqi exile political community in Amman, and Sihem Djebbi, a PhD candidate at the Paris Institute of Political Studies, who has been exploring the transnational networks of the Iraqi political and economic elite between Iraq, Syria, and Jordan.

15. For Damascus, see Mohamed Kamel Doraï, "Lexil irakien à Damas. Modes d'insertion urbaine et reconfiguration des réseaux migratoires," EchoGéo, no. 8 (2009), accessed 10/07/012, http://echogeo.revues.org/index10976.html; and Cyril Roussel, "Jeramana, voisine de Damas, ou le devenir d'une ville réceptacle de réfugiés irakiens," Revue de Géographie de l'Est 49, no. 4 (2009), (accessed 10/07/2012, http://rge.revues.org/2041).

16. Michael Kagan, "We Live in a Country of UNHCR': The UN Surrogate State and Refugee Policy in the Middle East," New Issues in Refugee Research, Research Paper no. 201 (2011).

17. Nicolas Seeley, "The Politics of Aid to Iraqi Refugees in Jordan,” MERIP 256 (2010), accessed 20/06/2012, http://www .merip.org/mer/mer256/politics-aid-iraqi-refugees-jordan.

18. On the substantial ideological obstacles to local integration of any migrants in Arab states see Gianluca Paolo Parolin, Citizenship in the Arab World: Kin, Religion and Nation State (Amsterdam: Amsterdam University Press, 2009), cited by Kagan, "We Live in a Country of UNHCR."

19. See [Iraqi] Refugees Return to Iraq May 2011-April 2012, UNHCR, accessed 10/07/2012, http://www.iauiraq.org /documents/1732/Refl-Ret-IRQ\%20Apr12.pdf.

20. http://www.unhcr.org/pages/4a16b1676.html.

21. See the contribution of Chantal Berman in this issue.

22. US Citizenship and Immigration Services, accessed 10/07/2102, http://www.uscis.gov/portal/site/uscis/ menuitem.5af9bb95919f35e66f614176543f6d 1a/ ?vgnextchannel $=68439 \mathrm{c} 7755 \mathrm{cb} 9010 \mathrm{VgnVCM} 10000045 \mathrm{f3}$ d6a1RCRD\&vgnextoid=df4c47c9de5ba110VgnVCM1000 004718190aRCRD.

23. Human Rights First, "Living in Limbo: Iraqi Refugees and US Resettlement," accessed 20/06/2012, http://www .humanrightsfirst.org/wp-content/uploads/Living-in -Limbo-final.pdf.

24. Géraldine Chatelard, "Cross-Border Mobility of Iraqi Refugees," Forced Migration Review no. 34 (2010).

25. The scale of the crisis was initially evaluated on the basis of information provided by Iraqi refugee-hosting governments which UNHCR is obliged by its Statute to accept. No host state has conducted a census of Iraqi nationals on its territory, and governments have not allowed international organizations to undertake independent counts. Since 2009, UNHCR has been operating strictly on the basis of registration numbers. By contrast, host governments and most international NGOs have continued to use high estimates in public documents, particularly funding appeals. On the challenges and politics underpinning refugee counts, see Jeff Crisp, "Who Has Counted the Refugees? UNHCR and the Politics of Numbers," New Issues in Refugee Research, Research Paper no. 12 (1999).

26. Harriett Dodd, "Iraqi Refugees in Jordan: The Challenges of Providing Assistance in an Opaque Environment," Refugeecooperation.org Project (2010), accessed 20/06/2012, http://www.refugeecooperation.org/publications/Iraq 104_dodd.php; Kate Washington, "Iraqis in Jordan: Urban Refugees, Data and the Implications for Emergency Education Programs," Refugeecooperation.org Project (2010), accessed 20/06/2012, http://www.refugeecooperation.org/ publications/Iraq/03_washington.php.

27. Enza di Iorio and Martine Zeuthen, "The Benefits of Engaging and Building Trust with a Reluctant Government: The Experience of Community Center for Iraqis in Syria," Refugeecooperation.org Project (2010), accessed 20/06/2012, http://www.refugeecooperation.org/ publications/Iraq/06_iorio.php.

28. Leenders, "Iraqi Refugees in Syria."

29. Géraldine Chatelard and Mohamed Kamel Doraî, "Les Irakiens en Syrie et en Jordanie : régimes d'entrée et de séjour et effets sur les configurations migratoires," CERISCOPE Frontières (2011), accessed 20/06/2012, http:// ceriscope.sciences-po.fr/content/part2/les-irakiens -en-syrie-et-en-jordanie.

Géraldine Chatelard is an independent researcher (http:// independent.academia.edu/GéraldineChatelard).

Tim Morris is an independent consultant (www.timmorris .info). 